\author{
Ugo Vlaisavljević \\ Univerzitet u Sarajevu, Filozofski fakultet, Franje Račkog 1, BA-71000 Sarajevo \\ vlaisugo5@gmail.com
}

\title{
Mare nostrum i čvrsto tlo fenomenologije
}

\begin{abstract}
Sažetak
$U » B e c ̌ k o m ~ p r e d a v a n j u «$ čitava je povijest svijeta u jednom trenutku naslikana u alegoriji valovitog mora bez obala. U Ideji fenomenologije se filozof-pripovjedač zatekao usred nemirnog mora, ali na kraju uspijeva »baciti kotvu na obalu fenomenologije«. S probojem na »kopno apsolutnih danosti« putem fenomenološke redukcije, alegorijsko prikazivanje trebalo je konačno izgubiti svoje filozofsko opravdanje. Međutim, metafore koje prizivaju alegorije nastavljaju bujati čak i u najstrožim fenomenološkim deskripcijama. No, usprkos svojoj inherentnoj metaforičnosti, tako živoj da se na ključnim točkama Husserlovih analiza često iznova pojavljuje mitski sukob zemlje i mora, fenomenološka interpretacija svijeta ipak u bitnom smislu nije alegorična.
\end{abstract}

\section{Ključne riječi}

more, tlo, Zemlja, valovi, alegorija, metafora, Edmund Husserl, fenomenologija

\section{Alegorija svjetskog mora}

Među tekstovima iz Husserlove zaostavštine, a koji pripadaju radovima oko Krize europskih znanosti, zasigurno posebno mjesto pripada »Bečkom predavanju « (Hua VI, str. 314-348). Poziv koji je Husserl dobio od bečkog Kulturbunda smatra se »vanjskim povodom « (Hua VI, str. xiii) koji ga je nadahnuo da započne raditi na novoj istraživačkoj stazi, čemu će posvetiti ostatak svog života. Upravo »Bečkom predavanju«, koje je održano 7. svibnja 1935., a zbog svog neočekivanog uspjeha ponovljeno tri dana kasnije na istom mjestu, u Austrijskom muzeju, pripada čast inicijalnog teksta onoga što će kasnije postati glavno djelo kasnog Husserla.

Kao Urtext i kao najvažniji dopunski tekst Krize, prvi i posljednji, središnji i marginalan tekst, »Bečko predavanje« može pružiti novo svjetlo u tumačenju Husserlova djela, po strategiji čitanja koju je Derrida nazvao »logikom nadopune ${ }^{1}{ }^{1}$ »Bečko predavanje« od svih se ostalih Husserlovih spisa izdvaja po svome adresatu pa, stoga, u načinu izlaganja. Taj način izlaganja, u kojem je širokoj publici trebalo predstaviti nimalo lake filozofske teme, otvorio je prostor oruđima retorike: slici, metafori, alegoriji, imaginarnom predstavljanju. Tu ćemo zateći Husserla u nesvakidašnje slikovitom govoru čiji smisao i svrhe možda daleko nadilaze jednu posebnu i po svemu izuzetnu prigodu.

$\mathrm{U}$ »Bečkom predavanju « postoje najmanje tri snažne retoričke slike: uvodna alegorija bolesnih europskih nacija koje, umjesto da ih liječe upućeni znanstvenici, pravi medicinari, kompetentni znanstvenici, u još gore muke guraju travari i nadriliječnici svojim »prirodnim metodama« liječenja; na kra-

1

Jacques Derrida je tu logiku, kasnije detaljnije elaboriranu, već primijenio u svom ranom djelu posvećenom »čitanju« Husserla (usp. Derrida, 1967, str. 97 i d.). 
ju predavanja nalazimo upečatljivu sliku Feniksa koji izranja iz pepela uz Husserlov, u tekstu jasno prepoznatljiv, a u izlaganju možda prigušen, povik da je »samo Duh besmrtan«, iza čega je morao uslijediti gromoglasan pljesak. Međutim, najviše nas zanima alegorija koja se pojavljuje negdje u sredini teksta, a trebala je ilustrirati Husserlovu tezu da su po svome bitnom određenju sve posebne nacionalne kulture različiti i karakteristični duhovni oblici koji stoje $\mathrm{u}$ »univerzalnom historijskom prostoru« te se kroz povijesne sklopove »koegzistencije i sukcesije« međusobno nadovezuju i pretaču tako da čine jednu jedinstvenu svjetsku povijest čovječanstva. Evo što je prethodilo moćnoj retoričkoj slici, što ona »ilustrira«:

»Svaki duhovni oblik na suštinski način stoji u univerzalnom historijskom prostoru ili u naročitom jedinstvu historijskog vremena sukladno koegzistenciji i sukcesiji, on ima svoju povijest. Krenemo li, dakle, slijedom historijskih povezanosti i, kako je to neophodno, od nas i naše nacije, onda nas historijski kontinuitet vodi sve dalje od naše $\mathrm{k}$ susjednim nacijama, pa tako od nacije do nacije, od jednog do drugog doba. U starom dobu konačno od Rimljana ka Grcima, k Egipćanima, Perzijancima itd.; tu očito nema kraja. Tako dospijevamo sve do pradoba i neće nam biti na odmet da posegnemo za značajnim i misaono bogatim Menghinovim djelom, za Svjetskom poviješću kamenog doba.« (Hua VI, str. 319)

Držimo li se ovog sveobuhvatnog povijesnog prostora, u jednom panoramskom pogledu »odozgo«, a polazeći od sadašnjeg vremena i vlastite nacije pa unatrag sve do prapovijesti, pred nama će se pojaviti impresivan prizor mora bez obala. Evo te slike:

»Pri takvom postupku čovječanstvo se ukazuje kao jedan jedinstveni, jedino putem duhovnih odnosa povezani život ljudi i naroda, s obiljem tipova ljudstva i kulture, no koji teku i jedni u druge se prelijevaju. To je kao more u kome su ljudi, narodi, kratkotrajno oblikovani, promjenljivi i iznova iščezavajući valovi, pri čemu su neki bogatije, kompliciranije, a drugi primitivnije namreškani.« (Hua VI, str. 319)

Pogledajmo pažljivo kako se pojavilo more u Husserlovu tekstu. Kao metafora koja je izravno proizašla iz dvaju odrednica na kraju prethodne rečenice, a koje opisuju kako se različiti tipovi ljudstva i kulture međusobno prožimaju: doslovce tako što su to tipovi koji su »tekući« (fließend) i »jedni u druge struje « (ineinanderströmend). Iz tako doslovno shvaćenog međuodnosa proizašla je usporedba s morem, metafora koja je otvorila prostor za ono što bismo mogli nazvati fenomenološkom alegorijom svjetske povijesti. ${ }^{2}$

Ne ostanemo li slijepi za živopisne slike koje nam nudi Husserlov diskurs, zaključit ćemo da samo zato što različiti tipovi ljudstava i kultura »teku« i »struje«, ulijevajući se jedni u druge, oni mogu biti pretvoreni u valove koji se gibaju u beskrajnom moru. Tako nam Husserl oslikava neograničen prostor ispunjen protjecanjima i strujanjima, razlijevanjima i ulijevanjima. To je prostor povijesti čovječanstva, »univerzalni historijski prostor« u kojem se ogromna morska masa kovitla i talasa. Tek se u ovom prostoru moćnog vodenog kretanja pokazuje da je svaki oblik ljudske zajednice i kulture ipak kratkotrajan i promjenljiv, a što je još važnije: nastaje i nestaje u pretakanju s drugim takvim oblicima. Svaki »duhovni oblik« (geistige Gestalt) - a s tim pojmom kasni Husserl promišlja posebnost i bit svake kulture - u milenijskoj kronologiji svjetske povijesti postaje lelujav i nestalan poput vala, a sva reljefnost njegovih unutarnjih crta nije ništa više od namreškanosti vodene površine.

No ipak, panoramski prizor mora, koji svakoj pojedinačnoj narodnoj kulturi dodjeljuje jedan valni Gestalt, ostaje kod puke morfologije, kod onoga što će Husserl u $\S 6$. Krize nazvati »pukim empirijskim antropološkim tipom《. Valovi pramora kako su opisani slikom upravo su takvi tipovi. Gestalt jedne kul- 
ture prepoznaje se $u$ onome što je invarijantno u svoj promjenljivosti lokalnih kulturnih oblika, ali fenomenolog ne može ostati pri takvoj eidetskoj analizi jer bi jedan pokraj drugog naprosto stajali morfološki tipovi poput antičke Grčke, Rima, Indije, Kine. Površinska namreškanost jednog vala - tj. koliko god bile kompleksne kulturne crte - nije dovoljna za pravi uvid u kretanja svjetske povijesti. Dakako, Husserl dopušta da postoje brojne zajedničke odlike različitih tipova kultura i naroda, uvodeći pojam »nadnacije«, ali »uz sve to se ne smije dozvoliti da puke morfološke općosti sakriju intencionalne dubine, tako da postanemo slijepi za najbitnije načelne razlike« (Hua VI, str. 328).

Treba, dakle, ići ispod površine mora, istraživati intencionalne dubine (intentionalen Tiefen) koje kriju fundamentalne razlike u načinima nabiranja mora. Stoga Husserl odmah u prvoj rečenici nakon alegorije mora napomenuti da je sada potrebno »unutra okrenuto promatranje« da bi se dokučile principijelne razlike i sličnosti među kulturnim tipovima. Dubina, pa i ona intencionalna, ostaje metafora, a takvu dubinu ne nudi nam samo more nego i vlastita duša. »Unutra okrenuto promatranje« može imati u vidu ne samo unutarnjost onog Augustinova čovjeka, na kojeg se poziva Husserl u posljednjoj rečenici $\mathrm{Pa}$ riških predavanja, nego i dubine onog mora koje za Husserl nije ništa drugo doli gibanje i komešanje duhovnih oblika.

Međutim, pred impresivnom slikom svjetskog pramora treba se upitati čija je to slika, pred čijim pogledom se ona pruža, tko je taj koji kulture može prepoznati kao kratkotrajne i promjenljive tvorevine. Iako ga je Husserl naslikao, to ipak nije prizor samo za fenomenologa. More se u njegovu izlaganju pojavilo u svjetlu izvjesne ideje o kulturi koja europsku kulturu još ne vidi bitno različitom od drugih kultura. Ništa još od morskih dubina nije tu došlo do pogleda jer su »različita historijska oblikovanja na jednu ravan postavljena« (Hua VI, str. 328). Fenomenolog se još ne razlikuje od kulturnog antropologa, etnologa, povjesničara. Europske nacionalne kulture još niti pokazuju svoje duboko srodstvo, niti neku bitnu razliku prema drugim kulturama. Tek se u dubinama povijesnih »tokova« $\mathrm{i} »$ strujanja«, do kojih mogu doprijeti jedino transcendentalno-fenomenološke analize, može spoznati da postoji samo jedna europska kultura i da ona nije nekoliko nabora morske površine, nego čitavo jedno more, more nas Europljana.

Ostanemo li slijepi za alegorijski prikaz upriličen na ključnom mjestu »Bečkog predavanja«, previdjet ćemo da je Europa za Husserla u stvari mare nostrum. No to ćemo moći shvatiti samo onda kada čitava slika nestane, potone u tminu pogleda koji zaranja, odsada okrenutog k najvećim dubinama samorefleksije. Nikakvim se slikama više ne može predstaviti metamorfoza ne jednog vodenog oblika među drugima, nego čitavog mora. Kultura koja više ne može biti kratkotrajna, koja je trajna kao svjetsko pramore, postaje u bitnom smislu nepredstavljiva, pogotovo ako se okrenemo k zasljepljujućem svjetlu koje dolazi sa samoga izvora, od nove ideje kulture položene u beskonačnost. Mogli bismo zaključiti da onoga časa kada transcendentalna fenomenologija nastupi u svojemu vlastitom elementu, u elementu samorefleksije i apsolutnih danosti, ponad puke morfologije kulturnih tipova i historijskih formi ili,

2

Zanimljivo je da je Husserl u svojoj ranoj skici »izvorne geneze svih apercepcija koje stvaraju zorno postojeći svijet« upravo kao primjer analogijskog simboliziranja, kada se »ono što je dano razmatra pod nekom slikom» naveo primjer "pravljenja i širenja valova« (Hua XXXIX, str. 419). 
radije, u njenim intencionalnim dubinama, metaforičnost će vode usahnuti. Husserlov znanstveni diskurs kao da više nema potrebe za živopisnim slikama. Međutim, ako transcendentalna fenomenologija kao stroga znanost i može bez (metaforike) mora, čini se ipak da ne može bez (metaforike) kopna. Ili bi možda točnije bilo reći da se u eidetskoj fenomenološkoj analizi prije transcendentalnog obrata još može ploviti, a da je transcendentalni stav nezamisliv bez čvrstoga tla. No i tamo, usred i podno tog tla, opet će se pojaviti tokovi i valovi.

Taj trenutak izlaska iz mora na kopno, kao metaforičan prikaz prelaska iz predfenomenološke, svjetovne, u posljednju fenomenološku stvarnost, Husserl opisuje mnogo godina prije, u svome prvom uvodu u transcendentalnu fenomenologiju iz 1907., da bi se još samo na kraju svog mislilačkog puta, $\mathrm{u} »$ ßBečkom predavanju«, vratio tako upečatljivo slikovitom prikazivanju. Tako u »Trećem predavanju « u Ideji fenomenologije nalazimo samog Husserla, doduše zajedno sa svojim zamišljenim čitateljima, kako »baca kotvu na morsku obalu fenomenologije« (Hua II, str. 45). Ova živopisna slika odjednom se pojavila kada mu je trebalo obrazložiti povratak u čistu imanenciju svijesti, dohvaćanje fenomena putem transcendentalne redukcije. Dok baca svoju kotvu, Husserla vidimo kako plovi po uzburkanom moru u pokušaju da se spasi od beznadnog lutanja i brodoloma, iako nam on čitav taj prizor tek ostavlja da naslućujemo. No zato nam nudi živopisnu sliku svoga mukotrpnog izlaska na suho:

»No sada su nužni novi koraci, nova promišljanja da bismo na novoj zemlji mogli čvrstom nogom stati [in dem neuen Lande festen Fuß fassen können] i da se ne bismo na kraju nasukali na njegovoj obali [Küste]. Jer ova obala ima svoje grebene, nad njom vise oblaci nejasnosti koji nam prijete skeptičnim olujama.« (Hua II, str. 45-46)

Na slici, na kojoj je ovaj put sam Husserl glavni lik, više nemamo samo more, kao kasnije u »Bečkom predavanju«, nego i more i kopno i nebo. Važno je najprije uočiti na što je to stao ili gdje se to iskrcao Husserl. Najprije treba reći da je to na »morskoj obali« jer bismo mogli pomisliti da je plovio rijekom. Upotrijebljena je riječ »zemlja« (Land) koja svoj doslovni smisao u njemačkom jeziku duguje razlici prema »moru«, a malo dalje u tekstu ista će referencija biti opisana kao »kopno danosti« (Festland von Gegebenheiten). Retorički dojmljivo djeluje dvostruko vezivanje pridjeva čvrst (fest), najprije uz čvrstu nogu ili stopu (festen $F u \beta)$, a potom u riječi kopno kao složenici (Festland). Husserl je također s idiomatskim izrazom festen Fuß fassen i to na »čvrstoj zemlji« (Festland) implicirao nesumnjiv spoznajno-teorijski smisao čitave slike: imati ili steći sigurno uporište, čvrst temelj, čvrsto postaviti, ustanoviti kao postojano; ali ne treba previdjeti niti: odomaćiti se i nastaniti se.

More tako predstavlja najveću prijetnju za fenomenologa, upravo zbog vodenih strujanja, nebo također, zbog zračnih strujanja, ali i vodene mase iz oblaka koja prijeti da se svaki čas sruči. Zasnovati fenomenologiju, držimo li se ovdje zadane metaforike, znači dokopati se kopna, čvrsto stati na pouzdano tlo. Fenomenolog je u bitnom, a ne tek slikovitom smislu onaj koji stoji, koji zauzima stav (Einstellung), uspravlja se na čvrstome tlu. Može se stajati na različite načine i na različitoj vrsti tla. Husserl je pokazao da se u prirodnom stavu stoji na zemaljskom tlu, a u teorijskom stavu na tlu koje više nije ni prirodno ni zemaljsko. Fenomenološki stav donosi - ili je trebao donijeti - ono što je teorijski oduzeo prirodnom stavu: apsolutno čvrsto i nepokretno tlo. No to je sada »transcendentalno tlo (transzendentale Boden). Kopno do kojeg je došao brodolomnik odmah je definirano kao »polje čiste spoznaje«. 
Iz svagda olujnog i nemirnog mora izlazi se pojedinačno, stazom fenomenološke egologije, u zadubljenosti u sebe samoga, kroz intencionalne dubine vlastite svijesti. Potpune utopljenosti u vodenom elementu rješavamo se putem transcendentalne redukcije. Prvi izlazak na sigurno kopno ima svoje ime pa Husserl nije nikog drugog mogao staviti na svoje mjesto. ${ }^{3}$ Izuzev fenomenologa, svi su ostali znanstvenici i istraživači načelno prepušteni lutanju na uzburkanom otvorenom moru, neprestanoj borbi s valovima daleko od svakog pristaništa ili im se poput očajnika na Splavi Meduze tek pričanja kopno.

Ali o kakvoj to čvrstoj zemlji uopće može biti riječi kada u meditaciji »sebi osiguramo polje čiste spoznaje« (Hua II, str. 46)? Kopno na koje je kotva bačena i na koje se uspinje utopljenik spasonosno je utoliko što je čvrsto i pouzdano: na njemu se može stajati, zauzeti »čvrst stav«. No čak i nakon svoga pristajanja na morsku obalu, fenomenolog ne može biti siguran. Prijetnja skepticizma i relativizma za apsolutno pouzdano znanje i dalje ostaje slikovito predstavljena burnim vodenim elementom. Nakon epskog izlaska iz mora nad fenomenologom su vodeni talozi koji se svaki tren mogu sručiti, kao što su pod njegovim nogama opasne šupljine $u$ tlu, izlokanom u grebene ili hridi ispunjene nemirnom morskom vodom. S tom preostalom vodom $\mathrm{u}$ škrapama će kasni Husserl imati velikih muka. Već tada se Husserl borio s najgorom slutnjom:

»Krećemo se u polju čistih fenomena. Ali zašto kažem polje; prije će biti da je to vječna heraklitovska rijeka.« (Hua II, str. 47)

Odjednom smo umjesto prizora mora dobili prizor snažno tekuće rijeke bez obala. Veoma je važan ovaj prelazak. Alegorija mora, ponovljena na dva važna mjesta u Husserlovu opusu, na početku i na kraju dugog puta u zasnivanju transcendentalne fenomenologije, služi da se živopisnim i dojmljivim slikama predstavi veliko postignuće fenomenološke filozofije: dolaženje do apsolutne izvjesnosti spoznaje. Metafora tla, najčešće, ali i zemlje ili kopna, služi da se obilježi ovo postignuće. Međutim, ne može se metafora tla shvatiti u svojoj funkciji u fenomenološkom diskursu - koja je očito veoma važna jer se ova metafora neprekidno i nanovo vraća u Husserlovim spisima i to na najvažnijim mjestima - bez svoje šire figurativne i tropičke pozadine: bez alegorije mora. Samo u alegoriji mora koja uključuje beskrajni prostor koji vrvi od metafora valova, strujanja, tokova, protjecanja itd., transcendentalni fenomenološki stav može biti predstavljen kao izlazak na kopno, kao osvajanje nove zemlje i stajanje na čvrstom tlu.

Transcendentalni obrat u (svojoj) filozofiji sam je Husserl upisao u trop »izlaska iz mora«. Potražimo li još kakvo mjesto u spisima iz tog doba u kojima se pojavljuje figura mora, naći ćemo je u čuvenom pismu koje je Husserl napisao Lévy-Bruhlu dva mjeseca prije »Bečkog predavanja« (11. III. 1935. - Husserl, 1994, str. 161). Ova figura opet dočarava najveću opasnost, ovaj put za antropologa ili nekog drugog učenjaka koji se bavi različitim ljudskim kulturama jer se može »utopiti u moru historijskih kulturnih tradicija, dokumenata, ratova, politika itd.«. Valovi se u pismu ne spominju, ali zadobivaju

Husserl u pismu Romanu Ingardenu (11. VI. 1932.) govori o svome prvom i usamljeničkom, poput »filozofskog pustinjaka«, »obrađivanju transcendentalnog tla« (Husserl,

1968, str. 79-80). U Ideen III govorit će o deskriptivnoj apriori fenomenologiji kao o prvom filozofskom nastojanju »obrađivanja transcendentalnog tla« (Hua V, str. 147-148). 
konkretan sadržaj jer ih ovdje vidimo kao »ljudstva koja žive zatvorena u živućoj generativnoj društvenosti« (Husserl, 1994, str. 162), od kojih svako ima »svoj svijet « drukčiji od ostalih. Mogućnost prelaska na čvrsto tlo iz nepreglednog mora, kako Husserl sugerira svome francuskom kolegi, osigurana je onog trenutka kada se uvidi da je u svakom od nebrojnih kulturnih oblika i povijesnih stupnjeva sadržana varijacija jednog sveprisutnog temeljnog odnosa - »konkretne korelacije čisto duhovnog života i oko svijeta kao njegove tvorbe važenja« (Husserl, 1994, str. 162). Prelazak s mora na kopno ima i jasan nefigurativan i epistemski oblik: kao prelazak s antropologije na »čistu unutarnju psihologiju « pa dalje, na transcendentalnu fenomenologiju. Zato će Husserl nakon alegorije mora pledirati za »unutra okrenuto promatranje«.

Kao i opća povijest, antropologija ima pred sobom more empirijskog materijala, ali nema čvrst kopneni ili zemaljski oslonac. S uspinjanjem fenomenologa na kopno pogled izvana (na svjetsko more) postaje pogled iznutra (na tokove vlastite svijesti pojedinca). Međutim, taj pogled, iako najprije shvaćen kao pojedinačno zaranjanje u morsku dubinu, niti će konačno izgubiti impresivnu panoramu mora, niti ostati usamljenički. Husserl će na drugim mjestima pojasniti čiji je to pogled koji može obuhvatiti čitavo more:

»Valja svratiti pozornost na to da je i ovo jedinstvo svijeta kao jedinstvo ljudskih okolnih svjetova također jedinstvo samo iz zbiljskog i mogućeg života svijesti koja nadgleda, ponovo oprisutnjuje.« (Hua XV, str. 398; Husserl, 1976, str. 250)

Zadaća je fenomenologa da iznese na vidjelo da je ukupan prirodno-povijesni svijet nastao iz intencionalnih tvorbi »transcendentalno-noetičke svjetske svijesti« i da ne može biti ništa drugo nego korelat transcendentalne intersubjektivnosti ili svesubjektivnosti (Hua XV, str. 391; Husserl, 1976, str. 245).

Alegorija spilje postala je alegorija mora: Platon izlazi kao zatočenik iz spilje, a Husserl kao iscrpljeni i očajni moreplovac iz mora. Samo zato što je more svjetsko, diluvijalni ocean bez obala, tlo kojeg se domogao Husserl transcendentalno je. Međutim, pokazat će se da ovo tlo nije ni posve suho ni čvrsto, nije čak ni nepokretno. Iako shvaćeno kao apsolutno i posljednje i ono stalno podrhtava i ljulja se na valovima, kao ona barka koju smo mogli sebi dočarati čitajući »Treće predavanje «Ideje fenomenologije.

Nakon borbe s uzburkanim morem ostaje neizvjesna borba sa strujama i tokovima, s rijekama i brzacima. Neće biti više mora, ali će biti valova. Husserl je posljednje godine svoga života posvetio mukotrpnom osvajanju nove zemlje ili posljednjim intencionalnim dubinama pramora, da bi dokučio i na svjetlo dana iznio praizvor svekolike transcendentalno-fenomenološke konstitucije. U konačnici, tamo gdje se već činilo da je »posljednje apsolutno tlo«, ukazalo se prapolje (Urfeld) uvijek već pokrenuto u prastruji (Urstrom) (Hua VIII, str. 10 i d.). ${ }^{4}$ Čak i tamo je vodena struja kao struja vremena (Zeitstrom) nagrizla i izlokala posljednje uporište fenomenologije.

\section{Valovi na apsolutno posljednjem tlu}

Istraživanja »polja svijesti« koja je kasni Husserl poduzeo, pogotovo ona posvećena unutarnjoj svijesti o vremenu, iznijela su na vidjelo strujeće jedinstvo svijesti koje ima svoje distinktivne momente, razdiobe u jedinstvenom toku, koje Husserl na nekoliko mjesta uspoređuje s valovima. Izdvojit ćemo nekoliko odlomka iz Husserlove zaostavštine, koji su neke tumače ovih istraživanja ponukali na raspravu o važnosti metafore vala. Najprije tri rečenice 
iz naknadne »Bilješke uz $§ 28 «$ Krize europskih znanosti, napisane u svibnju 1936. godine:

»Život je naše svijesti o svijetu [Weltbewusstseinsleben] kontinuirani tok 'doživljavanja' koji protječe u raznolikim posebnim doživljajima kao nesamostalnim momentima, kao takoreći valovima ovog toka. Svaki od njih nije tek 'val toka', dakle dio cjeline, cjeline života, nego je u svakom nešto doživljeno. Svaki posebno u sebi je imanje-svijesti o nečemu kao svome predmetu, kao onome što u njemu važi kao neposredno predstavljeno, s odgovarajućim 'sadržajem predodžbe' (ili također sadržajem smisla).« (Hua XXIX, str. 194)

Slika valovitog toka se, dakle, pojavljuje kada treba predstaviti momente ili dijelove jedinstvenog toka svijesti. S jedne strane, ovaj tok ne protječe sam od sebe, nepomućeno, kao strujanje koje nema nikakvih oscilacija, nikakvih promjena ili prijelaza, a s druge, dijelovi ili momenti cjeline toka ne mogu biti posve samostalne cjeline. Ako se tok niti može zaustaviti, niti njegovo jedinstvo raskinuti, a u njega se ipak moraju moći uvesti njegovi dijelovi, onda se ovi 'nesamostalni momenti' mogu pojaviti samo kao nabiranja neprekidnog vodenog toka, kao njegovi valovi. Život svijesti jest jedan jedinstveni tok, ali u stalnom i neprestanom talasanju. Život (Leben) je doživljavanje (Erleben): valovi toka svijesti ukazuju na to da tok u svakom trenutku zapljuskuje nešto čvrsto i postojano, tako da je svaki val ništa drugo nego poseban doživljaj (Erlebnis) nečega što stoji nasuprot svijesti: doživljaj predmeta. Stalno nabiranje toka svijesti nije ništa drugo doli intencionalna vezanost uvijek predmetne svijesti. Posebni doživljaji (Sondererlebnisse) kao nesamostalne cjeline neraskidivo su vezani uz posebne predmete (Sondergegenstände). Ovi predmeti, koliko god se pojavljivali kao samostalne cjeline u konstituirajućoj djelatnosti svijesti, ne mogu raskinuti jedinstvo svijesti: doživljaji se nižu kao valovi jednog jedinstvenog toka. A opet, nesamostalni momenti ovog toka nisu tek njegovo komešanje i nabiranje, nisu tek »puki valovi« jer se pojavljuju kao momenti otvorenosti svijesti prema svijetu, kao njeno zahvaćanje konkretnih sadržaja svijeta. U svakom valu postoji nešto više od samoga vala: neko »svjesno imanje«, predstavljeni, mnijeni, smisleni sadržaj. Upravo stoga je naš svjesni život u stvari »život svijesti o svijetu« (Weltbewußtseinsleben). Analiziramo li što je ljudsko iskustvo, uvidjet ćemo da se čovjek pojavljuje »kao subjekt imanja svijeta [Welthabe], važenja svijeta, kao subjekt mogućih, napredujućih, svagda novih horizonata otkrivajuće spoznaje« (Hua XXIX, str. 308).

Jasno je da se valovito gibanje može primijetiti samo na strani svijesti i to jedino očima fenomenologa. Jednako kao i to da su predmeti koji se u prirodnom stavu pojavljuju kao čvrsti i postojani uvijek već pokrenuti i rastvoreni u nekom doživljaju kao valu toka svijesti. Međutim, ako je svaki val posljedica nekog imanja predmeta u svijesti, doživljaja kao intencionalnog akta, sami su valovi nezamislivi bez prepoznavanja svijesti kao jednog jedinstvenog toka. Takav uvid upravo pruža fenomenolog ako uspije iznijeti na vidjelo da je $\mathrm{u}$ svakom aktualnom »sada« na djelu ne samo prolaženje i nestajanje, u kojem neki sadržaj svijesti namah prostruji, nego i izvjesna »univerzalna sinteza« koja sve aktualne momente svijesti čini povezanim, nesamostalnim, objedinjenim. Husserlov »korelacijski apriori«, koji podrazumijeva univerzalnu korelaciju bitka i svijesti, noeze i noeme (Hua III, str. 254, 306, 319; Hua VI, §

I jedno i drugo se podudaraju u Živoj Sadašnjosti (lebendige Gegenwart) kao »prafenomenu«, »kao posljednjem apsolutnom tlu« (Hua VIII, str. 35, b1). 
46), nalaže da se jedinstvo svekolikog toka svijesti istovremeno otkrije i kao svekoliko jedinstvo svih predmeta svijesti: kao svijet.

»U tom pogledu neka bude još istaknuto da su u aktualnom 'sada' života, u njemu svojstvenom strujećem-prostrujećem-bitku svi posebni doživljaji povezani u univerzalnoj sintezi i to tako da su sve predmetnosti koje su u njima predstavljive svagda u svojim važenjima bitka sjedinjene, na odgovarajući način svijesti, u totalitetu jednoga svijeta, kojem sve one pripadaju kao članovi, kao posebni predmeti. Svaka posebna svijest je moment kontinuirane, stalne, jedinstvene i strujeće totalne svijesti o svijetu koji ‘sve’ obuhvaća.« (Hua XXIX, str. 195)

Nekoliko redaka dalje u istom tekstu, Husserl zaključuje kako na jednoj strani imamo »univerzalnu sintezu koja čitav strujeći život u svim njegovim doživljajima sintetički sjedinjuje u više jedinstvo doživljavanja [Erleben]«, a na drugoj strani »sveobuhvatnu intencionalnu predmetnost: postojeći svijet« (Hua XXIX, 196). Ako svijest ni u kojem momentu nije nepomućen tok, ali ni puko, prazno, besadržajno talasanje jer je život »doživljavanje kao predmetno imanje-svijesti«, ni predmeti svijeta ne mogu ostati zatvoreni u nekoj nepomućenoj postojanosti i krutosti, odoljeti oscilacijama vodenog elementa. Ima još nekoliko živopisnih slika s valovima u Husserlovu opusu. Pored ovih navedenih iz grupe spisa oko Krize, za sljedeću bi se moglo reći da je jedna od najvažnijih, tim više što pripada $u$ djelokrug analiza unutarnje vremenske svijesti, u kojima se svijest pojavljuje prije svega kao tekuća i strujeća:

»U budnome životu stalno sam svjestan svijeta. Ova stalnost imanja-svijesti je jedno strujeće jedinstvo, ona je u ovome jedinstvu raznoliko imanje-svijesti, pri čemu postajem svjestan uvijek novih pojedinačnih stvarnosti i stvarnih kompleksa u /njihovoj/ posebnosti, a svi su također za sebe strujeći u promjenljivim posebnim svjesnostima. Ali uvijek je jedan tok koji sve ove posebne tokove takoreći kao valove u sebi skriva, a i jedinstvo svijesti, štoviše svijesti jednog $\mathrm{i}$ istog svijeta kao u izvjesnosti bivstvujućeg, čije odgovarajuće pojedinačnosti i kompleksne raznolikosti k meni 'nastupaju' i ponovo ‘odstupaju', za mene se izdižu ili podižu ili se slijevaju ili tonu.« (Hua Mat VIII, str. 362-363)

I ovdje u rukopisu, arhiviranom pod oznakom C 16, kao i u gore citiranom odlomku iz »Bilješke uz $§ 28$ « Krize, jedinstvo svijesti kao jedinstvo jednog jedinstvenog toka pokazuje se i kao jedinstvo jednog i istog svijeta. Pojavljivanje predmeta svijeta također se ponovo pokazuje kao mnoštvo različitih »imanja-svijesti«, što dovodi do pojave valova u ukupnom i jedinstvenom toku svijesti. Opet vidimo da nijedan val nije »tek val toka« jer život ne teče sam za sebe, nego je kao doživljavanje budne svijesti nerazlučivo vezan uz svijet čija je izvjesnost (Weltgewissheit), stoga, neupitna. Međutim, ono što sada vidimo u sceni s valovima jest to da valovi naprosto ne zapljuskuju ono što se čini kao relativno čvrsti obrisi »pojedinačnih stvarnosti i stvarnih kompleksa«, nego da su »svi /oni/ također za sebe strujeći«. Ono što je moglo izgledati kao čvrste hridi o koje udaraju valovi uskomešanog toka postaje i samo zahvaćeno lelujavim strujanjem. Pored posebnih doživljaja (Sondererlebnisse) i posebnih predmeta (Sondergegenstände) na koje su ovi prvi usmjereni, sada imamo i posebna strujanja (Sonderströme). Husserl će upravo zbog neprestanog pojavljivanja mnoštva zasebnih tokova predmetne svijesti tok svijesti preciznije označiti kao »jedinstveni stalni ukupni tok « (einheitliche ständige Gesamtstrom) (Hua Mat VIII, str. 363).

U dodatku koji je Husserl napisao uz retke citata iz »Bilješke uz § 28« Krize, a u kojem gotovo od riječi do riječi ponavlja svoju slikovitu usporedbu s valovima, naglašava se da »totalnu izvjesnost bitka svijeta« treba shvatiti »kao totalnu svijest o svijetu koji obuhvaća sve pojedinosti«, pri čemu se raskriva da je to što je svijet uvijek nešto unaprijed dano aktivnom subjektivitetu po- 
sljedica bitno »pasivne izvjesnosti svijeta«, a toga ne bi bilo da svjesni život svoju postojanost ne duguje »kontinuiranom podsloju pasivnog protjecanja doživljaja kao važenja bitka« (Hua XXIX, str. 487). U struji svijesti sam svijet teče namreškan u svoje pojedinačnosti. Osvrnemo li se ponovo na ono što nam je poetski dočarano na kraju posljednjeg navedenog citata, vidjet ćemo da se u valovima toka svijesti ovaj put sam svijet talasa: »pojedinačnosti i kompleksne raznolikosti k meni 'nastupaju' i ponovo 'odstupaju', za mene se izdižu ili podižu ili se slijevaju ili tonu«. Sada se onaj moreplovac kojeg smo evocirali u alegoriji iz Ideje fenomenologije ne može domoći čvrstoga tla jer ono što je izgledalo kao da se opire valovima i samo je valovito strujanje. Dakako da je to u skladu s temeljnim uvidom transcendentalne fenomenologije: ono što se na jednoj razini fenomenološke analize pojavljivalo kao zatečeno i postojano u-sebi-mirujuće, kao ono što se čvrsto opire uzburkanim strujama konstituirajuće svijesti, na nekoj se dubljoj razini pokazuje kao sedimentirana tvorevina iste te svijesti koja je u stanju naknadno oživjeti svoje prvobitne, prethodno pohranjene tokove ili, radije, nanose valova.

U istraživačkom rukopisu posvećenom Teleologiji u povijesti filozofije, Husserl u uvodnom dijelu, napisanom u srpnju 1937. godine, nekoliko puta koristi metaforu vala. Trebalo je tu osvijetliti posebnu narav poziva filozofa i to polazeći od uvida da svakom pozivu, bilo postolara ili filozofa, »odgovara njemu svojstvena zadaća«, a da takve zadaće treba shvatiti kao »habitualno postojane voljne ciljeve« (Hua XXIX, str. 364). ${ }^{5}$ Autor se tu upustio u kratku analizu intencionalnih struktura $\mathrm{i}$ »stvarno implicirane vremenitosti« (Hua XXIX, str. 366) kod nekog trajnog voljnog opredjeljenja kakvo je poziv. Usmjerenje naše volje k nekom cilju predstavlja habitualno držanje okrenuto budućnosti, ono otvara čitavo jedno »vremensko polje« kao »prednacrt« jednog »pred-imanja«, a ovu ustrajnost i vremensku postojanost Husserl određuje pojmom »voljne teze« (Willenthesis).

»Tek će kroz voljnu tezu prednacrt postati stvarno pred-imanje. Ali ova riječ u svome uobičajenom smislu ne znači nešto poput pukog 'voljnog akta', naime htijenja koje u strujećem životu svijesti iskrsne i prostruji, dakle, ne ono što imenujemo 'doživljajem' u 'doživljajnom toku', pored drugih sličnih doživljaja ('psihičkih akata'); radije voljna teza s njenim vlastitim 'sadržajem' (ciljem htijenja) neposredno zasniva na postojanom cilju postojano usmjerenu volju, postojanu ponad kratkotrajnog, prostrujećeg akta. Prema tome, kazuje iskaz: 'ja hoću' ovo ili ono, a ne tek ja trenutno imam doživljajni akt htijenja, ili čak, ja sam stvarno psihofizičko biće, zvano čovjek, u čijoj 'duši' ili u čijem se toku svijesti poput objektivnog događaja dešava nešto kao htijenje dakle, slično kako se u nekom stvarnom toku pojavljuje neki val i /u/ njemu prostruji - radije je u 'ja hoću' sadržano: sebi postavljam ili sam ranije postavio cilj pa sam stoga sada trajno - sve do daljnjeg - onaj koji je tako htio, koji ima takvu volju.« (Hua XXIX, str. 364-365)

Akt svijesti koji ima oblik »ja hoću«, odlučno usmjeren na neki »voljni sadržaj«, »cilj«, nije svediv na jedan doživljaj u nizu doživljaja. S takvim voljnim opredjeljenjem za »postojani cilj postojano usmjerene volje«, pojedinačni akt svijesti prestaje biti tek doživljaj koji je se u jednome trenutku pojavio i nestao - kao val u nekom stvarnom toku. U trećoj rečenici ovog citata pojavljuje se metafora vala, ali ona je također već pripremljena, ako ne i uvedena, u prethodnoj rečenici kada se htijenje nipošto ne želi izjednačiti s aktom ili doživljajem koji »u strujećem životu svijesti iskrsne i prostruji«. Treba ovdje

Hua XXIX: 364. Pozivom kao aktom volje, kao voljnom odlukom, Husserl se ranije detaljnije bavio, opet uzimajući poziv filozofa kao egzemplaran, kao tip života iz »apsolutne pozvanosti«. Važni uvidi o tome ušli su i u »Bečko predavanje« (usp. Hua VIII, str. 3-26). 
napomenuti da je u prvobitnoj verziji teksta Husserl i u ovoj prethodnoj rečenici spomenuo valove, ali ih je u naknadnom čitanju izostavio. ${ }^{6}$ Očito samo zbog nepotrebnog ponavljanja metafore, što opet govori koliko mu je ona bila važna u izlaganju.

Dok je u dva Husserlova citata koja smo prije ovog posljednjeg naveli upravo imanje-svijesti o predmetima svijeta činilo da akti svijesti nisu tek puki valovi jednog toka, sada pred-imanje sadržano u htijenju ima istu posljedicu. Dok u tim prethodnim citatima iskustvena imanja predmetnih sadržaja grade bogati i postojani reljef svijeta, ovdje voljna pred-imanja grade »habitus« i »karakter« subjekta, trajne crte pojedine ličnosti. U slučaju voljnog opredjeljenja u jednom trenutku najmanje imamo na djelu »vremenovanje nekog realiteta«, što bi takav doživljaj moglo učiniti samostalnom cjelinom analize. Posebni doživljaji (Sondererlebnisse) kod voljnih opredjeljenja ne donose posebne stvarnosti (Sonderrealitäten). Od stvarnosti nemamo ništa drugo nego »prednacrt« koji je »istinsko pred-imanje« (Vorhabe). Ispunjeno sadržajno imanje akata htijenja bilo bi njihovo izvršavanje (Ausführung) koje je upravo takvim aktima odloženo, ostavljeno za neki budući akt. Razlika između ove dvije različite upotrebe metafore vala još više dolazi do izražaja u nastavku teksta, gdje je izravnije tematizirano »imanentno vremensko polje« koje se otvara $s$ htijenjem i voljom:

»Htijenje kao ono što je jastvo izvršilo ulazi u moj ‘doživljajni tok'. Ali ono nije puki val ovog toka koji bismo kao konkretnu cjelinu mogli razložiti na njegove dijelove ili izložiti u njegove nesamostalne, apstraktne momente.« (Hua XXIX, str. 367)

Postoje, dakle, dvije različite upotrebe slike vala, ne računajući sada onu iz »Bečkog predavanja«, od koje smo najprije krenuli. Najprije je ono što val nosi predstavljeno kao nešto više od nesamostalnog dijela toka, a potom kao nešto manje od samostalnog dijela. U prvom slučaju biti više od vala znači da se dio cjeline života uklapa u dio cjeline svijeta, dok u drugom slučaju to znači da sami dijelovi cjeline života tek svojim povezivanjem grade život kao stvarnu i postojanu cjelinu. U prvom slučaju to je moguće zahvaljujući (relativnoj) punini sadržaja vodenog nabora, a u drugom, njegovoj (relativnoj) praznini.

Pri tome je potrebno razlikovati »nestvarni« (ne-objektivni) val u toku svijesti i stvarni (objektivni) val u toku prirodne stvarnosti. U prvoj upotrebi ima nešto stvarno u valu koji nije stvaran (u smislu predmetne objektivnosti, uključujući i psihički akt kao stvarni događaj). U drugoj upotrebi ima nešto nestvarno, posve subjektivno u doživljaju što ga nikako ne može izjednačiti s valovima u stvarnosti (koje bismo mogli smatrati »konkretnim cjelinama«). U prvom slučaju svijest nije svediva na valoviti tok jer ima svijeta i postoje trajni oblici predmetnosti. U drugom slučaju svijest nije svediva na valoviti tok jer i sama ima trajne oblike.

Za Husserla, svijest sa svojim intencionalnim sadržajima: jest tok jer je vremenska svijest i jer je vrijeme opća i temeljna forma svijesti; jest valovita jer protječe u fazama i momentima kao posebnim doživljajima ili aktima svijesti; i jest jedinstvena jer su ti momenti nesamostalni, podvrgnuti »univerzalnoj sintezi« svijesti.

Postoji još jedna slika s valovima kod Husserla. Dan Zahavi ju je pronašao u još neobavljenim Husserlovim spisima. Riječ je o dvije rečenice: 
U ovoj kratkoj opasci ne nalazimo ništa što već ne znamo iz prethodnih slika. Pa ipak, možda je važno u tumačenju spoznaja kasnog Husserla ovo njegovo izričito i naglašeno izjednačavanje figure vala s pojedinim doživljajnim aktom. Još je u Idejama I Husserl ukazao na tekuću prirodu samog doživljaja, smatrajući da je on »u samome sebi tok postajanja« (Fluß des Werdens). Takvo određenje, dakako, proizlazi iz jednostavnog osvrta na vremenski karakter doživljaja iz koga se vidi da je on »stalan/postojan tok retencija i protencija, posredovan kroz fazu prvobitnosti koja je i sama tekuća, u kojoj je živo Sada doživljaja svjesno naspram svojih Prije i Poslije« (Hua III, str. 182). No nije li s ovakvim određenjem doživljaja val postao kratkotrajan koliko i »moment živoga Sada« (Hua III, str. 183)? Nemamo li onda toliko valova koliko i neumitno i stalno prolazećih trenutaka? Vezivanje doživljaja uz stalno protjecanje potkopava mogućnost njihove eidetike, ako bi to značilo njihovu neponovljivost - tim više što su »dva doživljaja istog sadržaja nezamisliva« (Hua III, str. 203, 429) - pa ne čudi da Husserl odmah uz samu formulaciju »tok postajanja《 dodaje da je »doživljaj to što jest u izvornom proizvođenju nepromjenljivog tipa suštine«. Time je osigurana načelno neograničena ponovljivost doživljaja kao iteracija mogućih reproduktivnih modifikacija jednog istog tipa doživljaja koji je jednom zadat kao pradoživljaj (Urerlebnis) Takvi najizvorniji i najkonkretniji doživljaji koji ustanovljuju tipske suštine sigurno ne pripadaju sjećanjima, fantazijama i slično, nego opažanjima stvari svijeta. Postoje, dakle, valovi koji pokreću talasanje cjelokupnog toka svijesti i valovi koji su bezbrojne posljedice takve uzburkanosti.

Međutim, usprkos osiguranoj ponovljivosti doživljaja, ostaje i dalje problem njihove kratkotrajnosti. Stoga je važno uputiti na Husserlov uvid o tome kako su akti »uvijek mnogostruko međusobno prepleteni, povezani, utemeljeni« te zato treba razlikovati tako sabran »ukupan akt« (Gesamtakt), kao jedan akt, od drugih akata kao njegovih dijelova (Teilakte) (Hua VIII, str. 99-100). Bez takvog razlikovanja ne bi bilo moguće govoriti o motivu kao trajnom interesu usmjerenom na jednu određenu temu, pa onda niti o stavu (bilo teorijskom, bilo praktičnom ili nekom drugom) kao postojanom jedinstvenom aktu, što je od presudne važnosti za fenomenologiju.

Dakle, kada i gdje god imamo doživljajni tok, možemo evocirati sliku valova. No, s druge strane, metafora se vala pojavljuje uvijek kada treba ukazati na važnost ukupnog toka. Također, treba napomenuti da se tok svijesti talasa kada se radi i o pasivnim i o aktivnim tvorenjima svijesti, dok god ima osnova govoriti o posebnim doživljajima. I u pasivnim i u aktivnim tvorevinama konstituirajuće transcendentalne svijesti nalazimo na djelu jedinstveni strujeći ži-

Kako se može pročitati u redaktorskim napomenama priređivača Husserlovih rukopisa, u drugoj citiranoj rečenici nakon mjesta gdje stoji »psihičkih akata« stajalo je »svi kao valovi protječući«, da bi taj dio kasnije precrtao (Hua XXIX, str. 522).

7

Tako u $§ 37$ Kartezijanskih meditacija sažeto stoji: »Univerzum doživljaja koji sačinjavaju realni opstojnosni sadržaj transcendentalnog ego, komposibilan je samo u univerzalnoj formi jedinstva tijeka, u koje se svrstavaju sve njime protičuće pojedinačnosti.« - Husserl neće previdjeti da odmah u sljedećoj rečenici spomene ono što je na drugom mjestu zvao »parcijalno strujanje «, naime: »... taj najopćenitiji oblik svih posebnih oblika konkretnih doživljaja i u samom njihovom tijeku strujećih konstituiranih tvorevina.« - Hua I, str. 109; navedeno prema prijevodu Franje Zenka: Husserl, 1975, str. 102.

8

»Bewusstsein ist eine Einheit. Ein Akt ist nichts für sich, er ist Welle im Bewusstseinsstrom." - MS. LI 15, 2b, prema: Zahavi, 1999, str. 77; Zahavi, 2002, str. 18 
vot satkan od doživljaja, što je za Husserla upravo razlog da odbaci hipotezu u dvoslojnosti svijesti (Hua XXIX, str. 196). ${ }^{9}$ Prema tome, pred-refleksivni doživljaji kod pasivnih sinteza valovi su jednako kao i kod onih aktivnih. Doduše, kod pasivnih konstitucija doživljaji nisu akti svijesti poput onih u aktivnim konstitucijama pa se može uvesti razlika između doživljaja i akata. Međutim, da ne bi valovi bili ponekad doživljaji bez akata, Husserl koristi pojam akta u širem smislu.

Međutim, u krajnjim dubinama unutarnje svijesti o vremenu ipak se može nazrijeti izvjesna nevremenitost ili nepostojanje »vremena kojeg bismo uistinu tako trebalo nazvati«. Tamo se više uopće ne može govoriti o strujanju koje pretpostavlja metafora o valovima. Husserl je to objasnio na jednom važnome mjestu na koje ukazuje Zahavi kao na potvrdu da postoji »izvjestan ambigvitet inherentan metafori« (Zahavi, 2011, str. 20, n. 7), prije svega, zato što se slikom o valovima više ne možemo služiti da bismo objasnili krajnje jedinstvo života ili doživljavanja, a ostaje upitno nije li ipak »strujeća Živa Sadašnjost « zaseban sloj neovisan o toku doživljaja. Evo kako glasi to mjesto:

»Ova strujeća Živa Sadašnjost nije ono što smo drugdje i već prije transcendentalno-fenomenološki odredili kao tok svijesti ili tok doživljaja. To uopće nije 'tok' sukladno slici, dakle uistinu vremenska (ili pak vremensko-prostorna) cjelina, koja u jedinstvu neke vremenske ekstenzije ima kontinuirano sukcesivno pojedinačno postojanje (kroz ove vremenske forme individualizirano u svojim raspoznatljivim razmacima i fazama). Strujeća Živa Sadašnjost je 'kontinuirano' strujeće bivstvo i to ne u nekom jedno-izvan-drugog bivanju, ne u prostorno-vremenskom (svjetsko-prostornom), ne u 'imanentno-vremenskom' bivstvu ekstenzije (dakle ni u kakvom jedan-izvan-drugog, što će reći jedan-nakon-drugog, jedan-nakon-drugog u smislu jedan-izvan-drugog-postavljanja u vremena kojeg bismo uistinu tako trebalo nazvati).« (Hua XXXIV, str. 187) ${ }^{10}$

Gdje nema toka i strujanja, nema ni valova. Čini se da se vremenovanje u najvećoj dubini, kao Urzeitlichkeit, iz protjecanja pretvara u čvrsto tlo. No ono i dalje mora ostati vremenito jer inače ne bi moglo biti konstituirajući sloj ili razina svekolikog vremenovanja.

Svi glavni problemi koji se javljaju oko posljednjeg konstituirajućeg sloja, kako je to još Klaus Held pokazao, mogu se svesti na suštinsku dvosmislenost Žive Sadašnjosti, koja je za Husserla istovremeno i nepobitno strujeća i stojeća. ${ }^{11}$ Raskriven kao anonimno fungirajući, apsolutni tok, koji protječe i ne protječe, iz temelja uzdrmava sam opći program fenomenološke filozofije jer se načelno opire »refleksivnoj zornosti« (reflexive Anschaulichkeit), a zagonetnost Žive Sadašnjosti ugrožava samu fenomenologiju kao egologiju (Carr, 1987, str. 147) zato što »jastvo nije ništa drugo nego Živa Sadašnjost« (K. Held).

\section{Otklon od filozofske alegorije}

Ne dokazuje li valovito strujanje posljednjeg apsolutnog temelja da fenomenolog ipak nije uspio dobaciti svoju kotvu do kopna? Ne otkrivaju li analize najvećih intencionalnih dubina da čvrstog dna uopće nema? Ili da je »apsolutna metafora « (Baumgarten, 1998, str. 61), koja otvara sam prostor fenomenološkog istraživanja, kao metafora koje se ni na kojem konstitucionalnom stupnju ili razini svoje analize Husserl nije mogao osloboditi, metafora vodenog toka, a ne čvrstoga tla? Ne uvodi li se time naknadno i neizbježno čitava Husserlova filozofija u alegoriju mora ili, štoviše, u alegorijsko predstavljanje svijeta? Kako je to, recimo, Nietzsche uradio kada je trebalo iznijeti na vidje- 
lo istinu da je svijet »volja za moć - i ništa osim toga«. U fragmentu 1067 njegova posljednjeg djela čitamo:

»Ma znate li vi uopće što je meni 'svijet'? Trebam li vam ga pokazati u svome zrcalu? Ovaj svijet: čudovište od snage, bez početka, bez kraja, čvrsta, gvozdena količina snage, koja ne raste i ne opada, koja se ne troši nego samo preobražava, kao cjelina nepromjenljivo velika [...] kao sila koja je posvuda, kao igra sila i valova sila u isti mah jedna i mnoga, ovdje se nakuplja, a tamo se istovremeno smanjuje, more silâ koje same u sebi bjesne i snažno naviru, vječno se mijenjajući, vječno ponovo pritječući uz silne godine vraćanja, uz oseku i plimu svojih oblika [Gestaltungen] [...].« (Nietzsche, 1954, str. 915) $)^{12}$

Doista može izgledati začuđujućom velika sličnost ovog prizora i onog u »Bečkom predavanju«. Evo tu i mora koje je posvuda, bez početka i kraja, njegovog silnog komešanja i valova koji se čas nakupljaju čas smanjuju, kao pritjecanja i otjecanja, te oseke i plime. Još su na kraju kod Nietzschea i Gestaltungen kao valni oblici!

Međutim, Husserl nipošto ne bi pristao na alegorijski prikaz svijeta kao filozofsku, a ne tek retoričku interpretaciju svoje filozofije. To da nema više mora $\mathrm{u}$ "polju čistih fenomena«, ukazuje na to da nije riječ o privremenoj oseci, nego o povlačenju čitavog mora. ${ }^{13}$ No to možda nije i povlačenje same alegorije. Nije li upravo time otvoren prostor za jednu drugu sliku svijeta, onu rivalsku: po kojoj je u temelju svega kopno, zemaljsko tlo (jer na samome dnu dna ima stajanje, ima nepokretnosti)?

Ništa uvjerljivije ne pokazuje principijelni otklon Husserlove filozofije od alegorije kao njegovo otkriće da je posljednji temelj svih tijela i tjelesnih odnosa u životnom svijetu upravo Zemlja kao posljednje i nepokretno tlo. Jer je njegov čuveni spis o tome, s jedne strane, kao prikaz čitavog svijeta $\mathrm{u}$ kojem svakodnevno živimo doista ono što bi moglo pokrenuti filozofsku ale-

I na sljedećoj stranici autor će ponovo zaključiti da bi bilo krivo govoriti o »dvoslojnosti«.

10

Za tumačenje ovog mjesta vidi: Brand, 1955, str. 77-79. Od novijih tumačenja vidi npr. Zahavi, 2003, str. 177-179, n. 67.

11

»Jastvo kao centrirajuća životnost [Lebendigkeit] intencionalnog života može iskusiti svoj vlastiti sadašnji bitak na dvostruki način kao vremenski predmet: on se, s jedne strane, može dokučiti kao nešto što neprekidno struji [fortströmt], te se na taj način lokalizira, odnosno objektivizira na vremenskim mjestima ili nizovima vremenskih mjesta (kao trajanje); on može svoju svagda u prisustvu zatečenu Sve-Sadašnjost u intencionalom životu, s druge strane, iskusiti kao kvazi-nadvremensko ili, da kažemo s Husserlom, sve-vremensko uporno postojanje na način idealnih predmeta, kao jedno stojeće Sada [stehendes Jetzt] ('nunc stans'). Ova se tmina deskriptivno-zorno ne može rasvijetliti jer se jastvo pod pogledom samorefleksije nužno pokazuje ili kao vremensko-strujeći ili kao sve-vremensko-stojeći predmet, tj. uvijek već kao nešto što u jednom od oba načina konstituirano, a nikada kao ono posljednje konstituirajuće. Jedinstvo stajanja i strujanja, a time i istinska bit 'Žive Sadašnjosti' ostaje ne-predmetna, tj. anonimna.« (Held, 1966, str. x)

12

Navodimo po Stamaćevu prijevodu (Nietzsche, 1988, str. 492) koji smo značajno izmijenili da bismo ostali vjerni figurativnosti vodenog elementa.

13

Istražujući »horizont svijeta kao strukturirani prazni horizont«, Husserl će, točno godinu dana prije »Bečkog predavanja«, za taj horizont upotrijebiti metaforu mora, da bi o njegovom »induktivnom« ispunjavanju govorio kao o njegovom povlačenju, o »pretvaranju samog mora u kopno« (Hua XXXIX, str. 139). Ovdje je metafora mora u jednom trenu prizvala alegoriju (umnožavanja aperceptivnog iskustva svijeta: otok koji stalna narasta i more koje uzmiče, sve do u beskonačnost). No ipak smatramo da Brough griješi kada metafore vala $\mathrm{u}$ apsolutnom toku svijesti bez kolebanja povezuje s alegorijom mora (usp. Brought, 2010, str. 39-40). 
goriju, a, s druge strane, tu nema ustupka alegoriji. U Umsturzu, Zemlja nije metafora, kao što je to more $\mathrm{u}$ »Bečkom predavanju«. U ovom spisu nema ni mora ni valova, ali je mogao biti otvoren prostor za puku retoričku uporabu, za alegoriju prazemlje poput pramora jer i tu Husserl na jednom mjestu govori »o relativnim historijama« koje pripadaju »jednoj jedinstvenoj historiji [...] kao epizode« pa je »dakako moguće da ova prahistorija bude jedan skup naroda koji potpuno odvojeno žive i razvijaju se, s tim što jedni za druge leže u otvorenom, neodređenom horizontu zemaljskog prostora« (Husserl, 1940, str. 319). Nema sumnje da se u takav i prirodan i historijski prostor ${ }^{14}$ prepun različitih oblika mogla smjestiti alegorija zemlje kao što se smjestila alegorija mora. U §38 spisa Erfahrung und Urteil imamo gotovo istu široku sliku, ali ovaj put »naše Zemlje [unsere Erde] koja u sebe uključuje sve različite okolne svjetove s njihovim promjenama i prošlostima«, samo što Umwelten ovaj put nisu valovi, nego »dijelovi/komadi [Stücke] jednog istog objektivnog svijeta« (Husserl, 1972, str. 189). No upravo zbog svoga objektivnog postojanja ova terra nostra nije isto što i isključivo alegorijsko marre nostrum iz »Bečkog predavanja«.

Osvrnimo se na kraju još i na alegoriju mora iz Ideje fenomenologije. Kao i tamo, u Umsturzu se na jednom mjestu izlaganja pojavljuje plovilo, neki brod koji Husserl (u ovaj priči predstavljenog kao »brodsko dijete« koje nikada na zemaljsko tlo svojom nogom nije stupilo) doživljava kao »moju 'Zemlju', moj 'prazavičaj' " (Husserl, 1940, str. 319). Nekoliko stranica prije nalazimo i već poznatu sliku »posljednje ukotvljenosti u egu«. No usprkos analogiji, Husserlove fenomenološke, stroge kinestetičke analize izvornog iskustva svijeta života ne ostavljaju prostora alegoriji.

\section{Literatura}

Blumenberg, Hans (1998). Paradigmen zu einer Metaphorologie. Frankfurt na Majni: Suhrkamp.

Brand, Gerd (1955). Welt, Ich und Zeit: Nach unveröffentlichten Manuskripten Edmund Husserls. Haag: Martinus Nijhoff.

Brought, John B. (2010). "Notes on the Absolute Time-Constituting Flow of Consciousness«. U: Lohmar, Dieter; Yamaguchi, Ichiro (ur.), On Time - New Contributions to the Husserlian Phenomenology of Time. Dordrecht: Springer. Str. 21-49. doi: https:// doi.org/10.1007/978-90-481-8766-9_2.

Carr, David (1987). »The Problem of the Non-Empirical Ego: Husserl and Kant«. U: Carr, David. Interpreting Husserl: Critical and Comparative Studies. Dordrecht: Martinus Nijhoff. Str. 137-156.

Derrida, Jacques (1967). La voix et le phénomène. Pariz: PUF.

Held, Klaus (1966). Lebendige Gegenwart: Die Frage nach der Seinsweise der Transzendentalen Ich bei Edmund Husserl, Entwickelt am Leitfaden der Zeitproblematik. Haag: Martinus Nijhoff.

Husserl, Edmund (1940). „Grundlegende Untersuchungen zum Phänomenologischen Ursprung der Räumlichkeit der Natur«. U: Farber, Marvin (ur.). Philosophical Essays in Memory of Edmund Husserl. Cambridge (MA): Harvard University Press. Str. 307-326.

Husserl, Edmund (1950). Ideen zu einer reinen Phänomenologie und phänomenologische Philosophie (sv. 1). Haag: Martinus Nijhoff. [Hua III]

Husserl, Edmund (1952). Ideen zu einer reinen Phänomenologie und phänomenologische Philosophie (sv. 2). Haag: Martinus Nijhoff. [Hua IV]

Husserl, Edmund (1954). Die Krisis der europäischen Wissenschaften und die 
transzendentale Phänomenologie. Haag: Martinus Nijhoff. [Hua VI]

Husserl, Edmund (1956). Erste Philosophie (1923/24) (sv. 1). Haag: Martinus Nijhoff. [Hua VII]

Husserl, Edmund (1959). Erste Philosophie (1923/24) (sv. 2). Haag: Martinus Nijhoff. [Hua VIII]

Husserl, Edmund (1968). Briefe an Roman Ingarden. Haag: Martinus Nijhoff.

Husserl, Edmund (1972). Erfahrung und Urteil. Hamburg: Meiner Verlag.

Husserl, Edmund (1973). Die Idee der Phänomenologie: Fünf Vorlesungen. Dordrecht: Springer. [Hua II]

Husserl, Edmund (1973). Zur Phänomenologie der Intersubjektivität: Texte aus dem Nachlass (sv. 3) 1929-1935. Haag: Martinus Nijhoff. [Hua XV]

Husserl, Edmund (1976). Kartezijanske meditacije, sv. 2: prilog fenomenologiji intersubjektivnosti. Prev. Franjo Zenko. Zagreb: Izvori i tokovi.

Husserl, Edmund (1993). Die Krisis der europäischen Wissenschaften und die transzendentale Phänomenologie: Ergänzungsband, Texte aus dem Nachlass 1934-1937. Haag: Kluwer. [Hua XXIX]

Husserl, Edmund (1994). Briefwechsel. Dordrecht: Kluwer.

Husserl, Edmund (2002). Zur phänomenologischen Reduktion: Texte aus dem Nachlass (1926-1935). Dordrecht: Kluwer. [Hua XXXIV]

Husserl, Edmund (2006). Späte Texte über Zeitkonstitution (1929-1934): Die C-Manuskripte. Dordrecht: Springer. [Hua Mat VIII]

Husserl, Edmund (2008). Die Lebenswelt: Auslegungen der Vorgegebenen Welt und ihrer Konstitution: Texte aus dem Nachlass (1916-1937). Dordrecht: Springer. [Hua XXXIX]

Nietzsche, Friedrich (1954). Der Wille zur Macht. München: Carl Hanser.

Nietzsche, F. (1988). Volja za moć. Prev. Ante Stamać. Zagreb: Mladost.

Zahavi, Dan (1999). Self-Awareness and Alterity: A Phenomenological Investigation. Evanston (IL): Northwestern University Press.

Zahavi, Dan (2003). »Inner Time-Consciousness and Pre-reflective Self-Awareness«. U: Welton, Donn (ur.). The New Husserl: A Critical Reader. Bloomington (IN): Indiana University Press. Str. 157-180.

Zahavi, Dan (2011). »Objects and Levels: Reflections on the Relation Between TimeConsciousness and Self-Consciousness «. U: Husserl Studies 27 (2011) 1, str. 13-25. doi: https://doi.org/10.1007/s10743-010-9084-4. 


\title{
Ugo Vlaisavljević
}

\section{Mare nostrum and the Firm Ground of Phenomenology}

\begin{abstract}
In the "Vienna lecture", the whole of the world's history is at one moment depicted through the allegory of a wavy sea without borders. In The Idea of Phenomenology, the philosopherstoryteller is caught up in a heavy sea, but at the end, they finally manage to "drop the anchor on the shore of phenomenology". With the break into the "mainland of absolute givenness" through phenomenological reduction, allegorical representation should lose its philosophical justification. However, metaphors which evoke allegories continue to proliferate even in the most rigorous phenomenological descriptions. Despite its inherent metaphoricity, so vivid that at the crucial points of Husserl's analyses often reappears a mythical clash of land and sea, the phenomenological interpretation of the world seems nonetheless essentially non-allegorical.
\end{abstract}

\section{Keywords}

sea, ground, Earth, waves, allegory, metaphors, Edmund Husserl, phenomenology 